\title{
Evaluasi program pembinaan sepak bola usia dini
}

\section{Evaluation Program of an early age soccer coaching}

\author{
Lingling Usli Wargadinata ${ }^{1}$, Ruslan Rusmana ${ }^{2}$ Budiman $^{3}$ \\ ${ }^{1,2,3}$ Program studi PJKR, STKIP Pasundan, Cimahi, Jawa Barat, 40512, Indonesia
}

\begin{abstract}
Abstrak
Tujuan dari penelitian ini untuk mengevaluasi program pembinaan sepak bola usia dini di Jawa Barat. Metode yang digunakan evaluasi program dengan desain CIPP. Penelitian dilaksanakan di Jawa Barat dengan sampel atlet sepak bola usia dini. Hasil penelitian bahwa konteks program pembinaan sepak bola usia dini di Jawa Barat memiliki kesesuaian antara visi misi dan tujuan yang hendak dicapai. Input perencanaan pembinaan sepak bola usia dini belum dilengkapi dengan ketersediaan dokumen perencanaan latihan dan pedoman program. Proses Pelaksanaan Program pembinaan sepak bola usia dini di Jawa Barat dalam hal ini meliputi 1) pelaksanaan latihan, 2) pelaksanaan kompetisi 4)mProduk Program pembinaan sepak bola usia dini mampu meningkatkan kualitas atlet. Atlet sepak bola usia dini Jawa Barat mengalami peningkatan perkembangan fisiologis, perkembangan teknik dan perkembangan mental hal ini tercermin dari hasil try-out, try- in, kejuaraan bahkan tercermin selama proses latihan berlangsung.
\end{abstract}

Kata kunci: Evaluasi Program, Sepak Bola, Usia Dini.

\begin{abstract}
The purpose of this study was to evaluate an early childhood soccer coaching program in West Java. The method used program evaluation with the CIPP design. The study was conducted in West Java with a sample of early soccer athletes. The results of the study show that the context of an early childhood soccer coaching program in West Java has a match between the vision and mission and the objectives to be achieved. Planning input for early age soccer coaching has not been equipped with the availability of training planning documents and program guidelines. The Implementation Process of an early age soccer coaching program in West Java in this case includes 1) the implementation of training, 2) the implementation of the competition 4) product of the early childhood soccer coaching program is able to improve the quality of athletes. Early childhood soccer athletes in West Java experienced an increase in physiological development, the development of techniques and mental development was reflected in the results of tryouts, try-ins, championships and even reflected during the training process.
\end{abstract}

Keywords: Evaluation Program, Soccer, Early Childhood. 
Permainan sepakbola dewasa ini adalah salah satu olahraga terkenal yang dimainkan tim (Wargadinata \& Ishak, 2018). Seluruh lapisan masyarakat dunia terutama anak-anak, remaja dan pemuda sangat menyenangi olahraga ini. Dahulu permainan sepakbola hanya di gemari oleh kaum lelaki, sekarang bukan hanya kegemaran kaum lelaki, akan tetapi juga merupakan kegemaran kaum perempuan. Hal tersebut sama seperti yang di ungkapkan oleh (Yunisal, 2017).

Sistem pembangunan olahraga tidak bisa dengan cara instan apalagi Manajemen asal jalan, tetapi membutuhkan totalitas dan komitmen untuk membina olahraga secara sistemik dan mendukung (Fataha et al., 2013).

Sepakbola di Indonesia sekarang ini secara kuantitas juga mengalami perkembangan yang cukup pesat. Ratusan bahkan ribuan pemain sepakbola tersebar dimana-mana dan mereka tergabung dalam beberapa klub yang tersebar di seluruh Nusantara. Semua lapisan masyarakat menyenangi olahraga ini. Kelompok orang tua, pemuda, remaja, terutama anak-anak baik lakilaki maupun perempuan menyenangi permainan sepakbola. Sejalan dengan itu pertandinganpun digelar dimana-mana baik yang merupakan kompetisi resmi maupun tidak resmi.

Sisi lain prestasi sepakbola Indonesia belakangan ini mengalami keterpurulan baik di level Asia maupun Asia tenggara. Berbagai upaya telah dilakukan oleh Asosiasi Sepakbola Indonesia (PSSI) seperti penataran pelatih dan aparat pertandingan, menggunakan jasa pelatih asing, membentuk tim khusus yang mengikuti kompetisi di negara lain, mengirim beberapa pemain muda potensial untuk berlatih di negara lain, menyelenggarakan kompetisi profesional dan melakukan naturalisasi terhadap pemain asing, namun sampai saat ini hasilnya belum memuaskan, malah cenderung makin ketinggalan dibandingkan dengan negara lain seperti Thailand, Vietnam, dan Myanmar.

Dahulu tim Nasional Indonesia sekitar tahun lima puluhan sampai tahun tujuh puluhan disegani oleh negara-negara lain baik dikawasan Asia Tenggara maupun di Asia sehingga mendapat julukan "Macan Asia". Korea Selatan, Jepang, dan negara yang lainnya di kawasan Asia takut manakala berhadapan dengan Tim Nasional Indonesia.

Sejauh ini Asosiasi Sepakbola Indonsia (PSSI) belum pernah melakukan evaluasi yang mendasar dan komprehensip sehingga belum bisa diketahui secara pasti apa saja yang menjadi penyebab terpuruknya prestasi sepak bola Nasional Indonesia. Masih banyak kelemahan dan kekurangan yang dimiliki oleh pemain sepakbola Indonesia antara lain: menyangkut kemampuan pemain, karakter pemain, kemampuan pelatih, model kompetisi, sistem penghargaan yang diberikan, dan sarana latihan. Data yang bisa penulis kemukakan berkaitan dengan kemampuan pemain diantaranya menyangkut skill individu, visi bermain, koordinasi gerak, dan, daya tahan aerobik. Skill individu pemain seperti kualitas passing, slleding, dan 
shooting rata-rata pemain Indnesia kurang bagus, kemudian kemampuan pemain yang berkaitan dengan kecerdasan, rata-rata pemain sepak Indonesia kurang memiliki visi yang baik. Koordinasi gerak rata-rata pemain Indonesia kurang bagus, sehingga kemampuan teknik pemain Indonesia kurang maksmal. Daya tahan aerobik ( $V_{O 2} \max$ ) pemain Indonesia rata-rata di bawah 58, sehingga pemain-pemain Indonesia tidak mampu bermain all-out selama 90 menit. Kemudian kemampuan pemain yang berkaitan dengan mental, rata-rata pemain Indonesia kurang memiliki mental yang bagus karena cenderung emosional, kurang disiplin, dan agak malas. Demikian pula dukungan yang berkaitan dengan sarana lapangan baik kualitas maupun kuantitasnya masih sangat kurang. Untuk memperbaiki kelemahan-kelemahan tersebut dapat dilakukan dengan beberapa cara antara lain memperbaiki dan memaksimalkan pembinaan sepakbola usia dini.

Sudah saatnya sepak bola indonesia mengembangkan diri mengikuti perkembangan sepak bola modern (Prawira \& Tribinuka, 2016). Pembinaan sepakbola usia dini di Indonesia beberapa tahun belakangan ini mengalami perkembangan yang cukup pesat. Sekolah Sepak Bola (SSB) bermunculan dimana-mana, bagaikan jamur yang tumbuh di musim hujan. Demikian pula antusiasme masyarakat baik anak-anak, remaja, maupun orang tua terhadap permainan sepakbola kian hari kian meningkat.

Beberapa klub amatir disetiap kota dan kabupaten yang ada di Jawa Barat dan secara umum di Indonesia memiliki wadah untuk melakukan Pembinaan Sepak Bola Usia Dini (SSB) sendiri-sendiri, bahkan belakangan ini terutama di kota-kota besar banyak klub atau perusahaan yang membentuk wadah untuk pembinaan sepakbola usia dini dengan nama Akademi Sepak Bola. Setiap Pembinaan Sepakbola Usia Dini atau Akademi Sepakbola, pada dasarnya memiliki tujuan yang sama yaitu menampung dan membina anak-anak remaja dan usia dini dengan cara memberikan dasar-dasar teknik bermain Sepakbola yang baik agar kelak menjadi pemain sepakbola yang handal. Karena pada dasarnya merekapun latihan harus dilakukan dalam jangka waktu yang lama dan melibatkan banyak variabel fisiologis, psikologis, dan sosiologis (Bompa \& Haff, 2009).

Perubahan manajemen atau pengelolaan klub sepakbola dari amatir ke arah profesional seharusnya menjadi sesuatu yang harus disadari bersama oleh seluruh komponen dalam persepakbolaan di Indonesia bila prestasi dan industri menjadi visi seluruh insan sepakbola khususnya PSSI dan seluruh anggotanya (Sulistiyono, 2012). Penulis meyakini bahwa berbagai kegagalan tim sepak bola Nasional kita dan berbagai kelemahan atau kekurangan pemain Nasional kita merupakan salah satu indikasi dan dampak dari belum maksimalnya Pembinaan Sepak Bola Usia Dini dan Usia Muda di Indonesia. Jika kita mendorong anak-anak untuk mengembangkan berbagai keterampilan, maka anak-anak mungkin akan mengalami sukses di 
beberapa aktivitas olah raga dan akan mernpunyai kecenderungan dan keinginan untuk mengkhususkan serta mengembangkan bakat lebih lanjut (Tangkudung, 2012). Oleh karena itu, PSSI sebagai induk organisasi Sepak Bola tertinggi di Indonesia harus segera mencari solusi agar Pembinaan Sepak Bola Usia Dini ke depan dapat dikelola secara lebih baik hingga dapat menghasilkan pemain-pemain yang berkualitas. Tujuan permainan sepakbola untuk mencari kemenangan jangan dicampur adukkan dengan pameo sepakbola usia muda yang tidak mementingkan kemenangan (Danurwindo et al., 2017). Dan Perlu adanya evaluasi (Winarno, 2004) bahwa evaluasi merupakan suatu proses yang sistematis untuk menentukan nilai berdasarkan data yang dikumpulkan melalui pengukuran. Sedangkan menurut (Wirawan, 2011) Evaluasi harus didukung oleh informasi yang dapat digunakan untuk pembuatan keputusan dari beberapa pertimbangan dan menurut (Lazwardi, 2017). Dari urgensi permasalahan diatas penulis mencoba melakukan penelitian berkaitan dengan Pembinaan Sepak Bola Usia Dini dengan Judul Evaluasi Program Pembinaan Sepak Bola Usia Dini di Jawa Barat.

\section{METODE}

Penelitian ini menggunakan pendekatan evaluasi program studi kasus dengan metode deskriptif, yaitu mendeskripsikan pelaksanaan program pembinaan sepak bola usia dini menggunakan model evaluasi CIPP (context, input, process, and product) yang dikembangkan oleh Daniel L. Populasi penelitian ini sekolah sepakbola di Jawa Barat. Teknik pengumpulan data yang digunakan mengambil sampel dari beberapa kota dan kabupaten, dan setiap kabupaten kota dipilih 8 orang yang terdiri dari satu orang pengurus, dua orang pelatih, dan lima orang siswa SSB. Instrumen yang digunakan adalah wawancara terbuka, angket dan studi dokumentasi.

\section{HASIL DAN PEMBAHASAN}

Sesuai dengan model evaluasi yang digunakan yaitu model CIPP ,evaluasi di lakukan pada aspek konteks, input, proses dan produk. Pengambilan data evaluasi terhadap empat komponen dilakukan dengan wawancara, angket dan studi dokumentasi.terhadap temuantemuan pada setiap data yang diperoleh kemudian dilakukan analisis data dengan membandingkan antara hasil analisis dengan kriteria pada setiap komponen evaluasi dilanjutkan dengan membuat penilaian dan keputusan. Hasil evaluasi masing-masing evaluasi konteks mencakup masalah yang berhubungan dengan lingkungan program yang telah dilaksanakan. Evaluasi konteks meliputi tiga aspek yaitu tujuan program pembinaan sepak bola usia dini di Jawa Barat, landasan hukum program pembinaan sepak bola usia dini di Jawa Barat, dan analisis kebutuhan. Hasil evaluasi konteks dari 36 responden 4 orang $(11,11 \%)$ menyatakan baik 
sekali, 6 orang $(16,67 \%)$ menyatakan baik , 5 orang $(13,89 \%)$ menyatakan cukup dan 21 orang $(58,33 \%)$ menyatakan kurang. Adapun hasil disajikan pada table sebagai berikut:

Tabel 1. Hasil evaluasi konteks

\begin{tabular}{lllc}
\hline \multicolumn{3}{c}{ Frekuensi } & Kategori \\
\hline No & Absolut & Persentase & Baik Sekali \\
\hline 1 & 4 & $11,11 \%$ & Baik \\
\hline 2 & 6 & $16,67 \%$ & Cukup \\
\hline 3 & 5 & $13,89 \%$ & Kurang \\
\hline 4 & 21 & $58,33 \%$ & \\
\hline & 36 & $100 \%$ & \\
\hline
\end{tabular}

Berdasarkan data tersebut diatas menunjukan bahwa hasil evaluasi program dengan model CIPP pada program evaluasi pembinaa sepak bola usia dini di Jawa Barat secara keseluruhan memiliki hasil evaluasi yang kurang dan belum sesuai dengan program yang akan dicapai. Tabel tersebut menunjukan bahwa dari 36 responden dengan menggunakan skala likert dengan indikator konteks,input,proses dan produk yang memberikan respon kurang sebesar $58,33 \%$ artinya berdasarkan kreteria keberhasilan evaluasi program maka belum sesuai dengan apa yang di harapkan baik secara konteks, input, proses dan produk. Sedangkan yang menyatakan kurang sebesar 56,33\% dari 21 responden.

Adapun secara detail penelitian jabarkan sebagai berikut Tujuan Program Pembinaan Sepak Bola Usia Dini di Jawa Barat. Berdasarkan studi dokumentasi penelitian memperoleh data bahwa pembinaan sepak bola usia dini memiliki kedudukan penting dalam kerangka pembinaan prestasi olahraga di Indonesia secara keseluruhan . proses pembinaan prestasi sepak bola di Jawa Barat memiliki keterkaitan pencapaian prestasi pada jenjang pelajar . ditinjau dari konsep teoritik usia pembinaan sepak bola usia diniberada pada tingkat kedua (level-2) dalam pembinaan prestasi tujuan sepak bola usia dini adalah pembibitan atlet pada level pelajar. Hal ini di perkuat oleh hasil wawancara dengan pelatih yang menyatakan hal serupa bahwa sepak bola usia dini merupakan wadah pembibitan atlet pada level pelajar. Kriteria keberhasilan evaluasi konteks pada indikator tujuan program sepak bola usia dini adalah belum terdapat kesesuaian tujuan sepak bola usia dini di Jawa Barat dengan visi misi. Berdasarkan pengecekan data antara hasil wawancara, studi dokumen dapat disimpulkan bahwa belum terdapat kesesuaian antara tujuan program pembinaan sepak bola usia dini dengan visi, misi. Landasan hukum program Sepak Bola Usia Dini DI Jawa Barat. Berdasarkan hasil wawancara diperoleh data bahwa pelatih, dan atlet menganggap landasan hukum program pembinaan usia dini di Jawa Barat belum cukup kuat karena pelaksanaan pembinaan sepak bola usia dini hanya di bawah koordinasi dinas pendidikan dan kebudayaan daerah di provinsi Jawa Barat, kriteria keberhasilan evaluasi konteks pada indikator landasan hukum program pembinaan sepak bola 
usia dini di Jawa Barat adalah belum adanya hukum yang kuat. Berdasarkan pengecekan data antara hasil wawancara, studi dokumen dapat disimpulkan bahwa pelaksanaan program pembinaan sepak bola usia dini belum memiliki dasar hukum yang kuat .

\section{Analisis kebutuhan}

Latar belakang terbentuknya sepak bola usia dini awalnya pembinaan olahraga khususnya pelajar di laksanakan oleh kanwil depdiknas tetapi setelah otonomi daerah tanggung jawab diberikan kepada dinas pendidikan dan kebudayaan daerah. melalui bidang olahraga daerah-daerah yang memiliki potensi yang bagus diberikan kewenangan untuk membentuk pembinaan sepak bola. Hal tersebut diperkuat dengan hasil wawancara pelatih yang menyatakan bahwa pemilihan cabang olahraga sepak bola usia dini berdasarkan kontribusi capaian prestasi olahraga di daerah tersebut dengan capaian prestasi olahraga di level nasional bahkan sampai level internasional. Misalnya Jawa Barat salah satu daerah yang terkenal sebagai salah satu pencetak atlet sepak bola maka cabang olahraga sepak bola menjadi salah satu cabang olahraga yang masuk dalam pembinaan sepak bola usia dini di Jawa Barat. Kriteria keberhasilan evaluasi konteks pada indikator analisis kebutuhan adalah belum terdapat kesesuaian program pembinaan sepak bola usia dini dengan kebutuhan yang ada. Berdasarkan pengecekan data antara hasil wawancara, studi dokumen dapat disimpulkan bahwa adanya pembinaan sepak bola usia dini belum sesuai dengan analisis kebutuhan di masing-masing provinsi, dalam penelitian ini provinsi Jawa Barat.

\section{Evaluasi input}

Evaluasi input meliputi ketersediaan sumber daya penunjang program pembinaan sepak bola usia dini di Jawa Barat. Adapun aspek yang menjadi indikator dalam evaluasi input antara lain ketersediaan rencana program, ketersediaan sumber daya manusia, dukungan organisasi penyelenggara, ketersediaan sarana dan perasarana, ketersediaan dana. Hasil evaluasi input dari 36 responden menyatakan 2 orang $(5,56 \%)$ menyatakan baik sekali, 9 orang $(25 \%)$ menyatakan baik dan 19 orang $(52,78 \%)$ menyatakan cukup, 6 orang $(16,67 \%)$ menyatakan kurang.

Tabel 2. Hasil Evaluasi Input

\begin{tabular}{lcll}
\hline & Frekuensi & & \\
\hline No & Absolut & Persentase & Katagori \\
\hline 1 & 2 & $5,56 \%$ & Baik Sekali \\
\hline 2 & 9 & $25 \%$ & Baik \\
\hline 3 & 19 & $52,78 \%$ & Cukup \\
\hline 4 & 6 & $16,67 \%$ & Kurang \\
\hline & 36 & 100 & \\
\hline
\end{tabular}

\section{Ketersediaan rencana program}


Berdasarkan studi dokumen bahwa sepak bola usia dini Jawa Barat dalam pelaksanaanya menyediakan buku pedoman pedomana pelaksanaan dan buku petunjuk teknis yang berasal dari kemendiknas, Kriteria keberhasilan input pada indikator ketersediaan rencana program adalah adanya dokumen perencanaa latihan dan pedoman program. Berdasarkan pengecekan data antara hasil wawancara, studi dokumen dapat di simpulkan bahwa sepak bola usia dini dilengkapi dengan ketersediaan dokumen perencanaan latihan dan pedoman program.

\section{Ketersediaan sumber daya manusia}

Dalam rangka mewujudkan tujuan program sepak bola usia dini maka di perlukan dukungan sumber daya manusia yang handal. Dalam penelitian ini peneliti lebih menyoroti pada dukungan atlet dan pelatih. Berdasarkan studi dokumen peneliti memperoleh data bahwa persyaratan menjadi atlet sepak bola usia dini Warga negara Indonesia, Mendapatkan rekomendasi dan induk organisasi cabang olahraga, Memiliki nilai akademik yang bagus, Usia maksimum 14 tahun atau kelas 1 SMU atau yang sederajat, Berbadan sehat, tidak merokok, tidak terlibat narkoba dan tidak pidana, Memiliki persyaratan keberkatan dalam cabang olahraga tertentu (kualitas biometric, kapasitas biometric, kualitas psikologi), Mendapat persetujuan dari orang tua/wali.

Pada dasarnya persyaratan menjadi atlet sepak bola usia dini juga dipengaruhi oleh kebijakan masing-masing daerah. sepak bola usia dini Jawa Barat dalam perekrutan atlet juga memperhatikan dari hasil kejuaraan yang diikuti oleh atlet. Misalnya ada atlet yang juara 1 dalam kejuaran maka atlet ini mendapatkan nilai tambahan sebagai bahan pertimbangan untuk lolos pada seleksi atlet sepak bola usia dini. Hal ini juga di perkuat dari hasil wawancara pelatih bahwa untuk mencari atlet yang masuk dalam sepak bola usia dini Jawa Barat biasanya penjaringan dilakukan dari hasil tes. Sedangkan untuk persyaratan menjadi pelatih Sepak bola usia dini Jawa Barat antara lain Memiliki sertifikat pelatih minimal tingkat daerah dan atau di setuji dan direkomendasikan oleh pemda cabang olahraga yang terkait KONI daerah, Berpendidikan minimal sarjana muda atau yang sederajat, Memiliki kemampuan dalam melaksanakan tugas dan fungsinya sebagai pelattih (terutama menyusun, melaksanakan dan mengevaluasi program latihan), Memiliki dedikasi dan tanggung jawab yang tinggi.

Profil pelatih sepak bola usia dini sudah sesuai dengan ketetapan peraturan pelatih sepak bola usia dini di Jawa Barat. Proses seleksi pelatih dilakukan oleh ditunjuk pihak pengurus Olahraga Jawa Barat berdasarkan rekomendasi dari dinas pendidikan dan kebudayaan provinsi lampung. Hal ini dilakukan agar antara dinas pendidikan dan kebudayaan Jawa Barat dan dinas pemuda dan olahraga selalu menjalin koordinasi. Seperti yang diungkapkan oleh kepala dinas pemuda dan olahraga Jawa Barat. Bpk. Dr.Yuda Munajat Saputra, bahwa harus selalu ada koordinasi antara dinas pendidikan dan kebudayaan dengan dinas pemuda dan 
olahraga dalam hal seleksi pelatih maupun atlet, bahkan untuk seleksi atlet harusnya dinas pendidikan dan kebudayaan menjalin kerjasama dengan dinas pemuda dan olahraga.

Kriteria keberhasilan evaluasi input pada indikator dukungan sumber daya manusia adalah terdapat kesesuaian profil dan proses perekrutan atlet, pelatih dengan kriteria yang ditetapkan sepak bola usia dini Jawa Barat berdasarkan pengecekan data antara hasil wawancara, studi dokumen dapat disimpulkan bahwa terdapat kesesuaian profil dan proses perekrutan atlet, pelatih dengan kriteria yang di tetapkan sepak bola usia dini Jawa Barat.

\section{Dukungan organisasi penyelenggara}

Berdasarkan hasil wawancara terungkap bahwa pelaksanaan sepak bola usia dini di Jawa Barat belum mendapatkan dukungan dari berbagai pihak antara lain dinas pendidikan pemuda dan olahraga. Kriteria keberhasilan evaluasi input pada indikator dukungan organisasi penyelenggara adalah terjalinnya kerjasama yang baik antara stakeholder yang ada berdasarkan pengecekan data antara hasil wawancara, studi dokumen dapat disimpulkan bahwa untuk mendukung sepak bola usia dini Jawa Barat belum terjalin kerjasama yang baik antara stakeholder yang ada .

\section{Ketersediaan sarana dan prasarana}

Ketersediaan sarana dan perasarana pada Ssepak bola usia dini Jawa Barat belum di dukung belum di dukung kebijakan dari dinas pemuda dan olahraga maupun dukungan KONI , pemda bahkan mendapat dukungan dari kemenpora . pada tahun 2014 kebijakan dinas pendidikan dan kebudayaan untuk mendukung pembinaan Olahraga tercermin dari di bangunnya beberapa sarana olahraga, sedangkan beberapa cabor mendapatkan bantuan alat. Kriteria keberhasilan evaluasi input pada indikator ketersediaan sarana dan prasarana adalah tersedianya prasarana dan sarana olahraga yang memadai. Berdasrkan pengecekan data anatar hasil wawancara studi dokumen dapat di simpulkan bahwa sepak bola usia dini Jawa Barat mendapatkan dukungan sarana dan prasarana yang belum memadai.

\section{Ketersediaan dana}

Ketersediaan dana merupakan salah satu aspek penting dalam mendukung sepak bola usia dini Jawa Barat. Sumber dana sepak bola usia dini di Indonesia anggarannya berasal dari APBD yang telah dialokasikan melalui dana kemenpora selain itu terdapat sumber dana sektoral, dana alokasi umum daerah dan swadaya lainnya. Berdasrkan hasil wawancara sumber dana sepak bola usia dini Jawa Barat dipergunakan untuk konsumsi, perlengkapan alat, peralatan sekolah dan latihan, pembangunan untuk gedung, lapang, transportasi, suplemen , honor pelatih, uang saku atlet. Kriteria keberhasilan evaluasi input pada indikator ketersediaan dana adalah tersedianya dana. Berdasarkan pengecekan data antara hasil wawancara studi dokumen dapat disimpulkan bahwa sepak bola usia dini Jawa Barat mendapat dukungan dana 
yang berasal dari APBN, sumber dana sektoral dana alokasi umum daerah dan swadaya lainnya.

\section{Evaluasi proses}

Pada hasil evaluasi process akan di bahas antara lain 1) pelaksanaan program, dan 2) pengawasan. Adapun hasilnya sebagai berikut : hasil evaluasi proses dari 36 responden menyatakan 1 orang $(2,78 \%)$ menyatakan baik sekali, 4 orang $(11,11 \%)$ menyatakan baik, 11 orang $(30,58 \%)$ menyatakan cukup, 20 orang $(55,56 \%)$ menyatakan kurang. Adapun hasilnya di sajikan pada table 3 sebagai beikut:

Tabel 3. Hasil Evaluasi Proses

\begin{tabular}{lcll}
\hline & Frekuensi & & \\
\hline No & Absolut & Persentase & Katagori \\
\hline 1 & 1 & $2,78 \%$ & Baik Sekali \\
\hline 2 & 4 & $11,11 \%$ & Baik \\
\hline 3 & 11 & $30,56 \%$ & Cukup \\
\hline 4 & 20 & $55,56 \%$ & Kurang \\
\hline
\end{tabular}

Pada hasil evaluasi process akan di bahas antara lain pelaksanaan program, dan pengawasan. Adapun hasilnya sebagai berikut:

\section{- Pelaksanaan program}

Pada pelaksanaa program lebih memfokuskan pada pertanyaan bagimana pelaksanaan program latihan sehari-hari?, bagaimana pelaksanaan program kompetisi ? bagaimana pelaksanaan program akademik? Bagaimana program kesejahteraan? Secara detail peneliti jabarkan. Pelaksanaan program latihan di sepak bola usia dini Jawa Barat berdasarkan kebijakan masing-masing pelatih cabang olahraga. Tempat latihan masing-masing cabor berdasarkan ketersediaan sarana dan prasarana. Ketersediaan pelatih dalam proses latihan dibagi menajdi pelatih fisik dan pelatih teknik. Dalam pelaksanaannya pelatih fisik dan pelatih teknik selalu berkordinasi untuk menentukan program latihan untuk atlet. Pelatih selalu mengevaluasi atletnya selama proses latihan berlangsung bahkan hasil evaluasi ini akan dijadikan sebagai bahan untuk menentukan atlet ini terdegradasi atau masih tetap dibina di sepak bola usia dini Jawa Barat. Proses degradasi biasanya dilakukan di akhir tahun yaitu pada bulan desember. Pelaksanaaan kompetisi disesuaikan dengan agenda kejuaraan sepak bola usia dini Jawa Barat. Pada hasil wawancara terungkap bahwwa tidak semua agenda kejuaraan sepak bola usia dini diikuti oleh semua klub sepak bola usia dini, hal ini menimbulkan kecemburuan. padahal hasil kejuaraan kejuaraan menjadi bahan evaluasi atlet. Terugkap juga bahwa tidak semua cabang olahraga. Pelaksanaan program akademik di Sepak bola usia dini tidak terlepas dari berbagai kendala. Kendala yang sering terjadi adalah atlet cenderung memiliki beban ganda karena atlet 
di tuntut untuk berprestasi di bidang olahraga, sedangkan kurikulum yang di gunakan masih menyamakan dengan siswa pada umumnya. Hal ini mengakibatkan bahwa jadwal latihan atlet selalu berbentrokan dengan agenda proses belajar mengajar di sekolah. Pelakasanaan program kesejahteraan pelatih pada dasarnya terkendala pada pencarian dana yang lambat dan jumlah uang saku yang kecil. Hal lain juga terungkap melalui wawancara bahwa masing-masing sekolah sepak bola usia dini di Indonesia memiliki kebijakan sendiri sehingga uang saku pelatih di tentukan oleh setiap sekolah sepak bola usia dini. Uang saku untuk pelatih berkisar antara Rp 400.000.00 sampai dengan Rp 1.000.000.00 setiap bulan.. Kriteria keberhasilan evaluasi proses pada indikator pelaksanaan program adalah terdapat kesesuaian pelaksanaan latihan, pelaksanaan kompetisi, peningkatan akademik dan kessejahteraan dengan yang ditetapkan pada ketentuan di pembinaan sepak bola usia dini Jawa Barat. Berdasarkan pengecekan data hasil antara hasil wawancara, studi dokumen dapat di simpulkan bahwa pembinaan sepak bola usia dini dalam pelaksanaan program latihan, pelaksanaan kompetisi, peningkatan akademik dan kesejahteraan sudah sesuai dengan yang di tetapkan pada di sepak bola usia dini Jawa Barat hanya saja masih perlu antara perbaikan antara lain dibutuhkan kurikulum khusus untuk atlet, peningkatan kesejahtaraan atlet.

- Pengawasan

Berdasarkan hasil wawancara proses pengawasan dilakukan sebagai sarana untuk mengevaluasi pelaksanaan pembinaan sepak bola usia dini. Evaluasi berkaitan dengan kinerja atlit, kinerja pelatih dan pengelola. Evaluasi terhadap atlit yaitu evaluasi terhadap kinerja dan perkembangan prestasi atlet yang di lakukan secara periodik, aspek yang dievaluasi meliputi prestasi dalam cabang olahraga yang ditekuni, prestasi akademik di sekolah, kepribadian atlet seta aspek-aspek, lain yang dipandang relevan, evaluasi dilakukan oleh unsur-unsur yang terkait dengan sepak bola usia dini Jawa Barat (KONI, PENGPROV, Dinas Pendidikan dan Kebudayaan), hasil evaluasi selanjutnya ditindak lanjut sebagai bahan untuk menentukan apakah atlet tersebut dapat di bina terus di sepak bola usia dini atau tidak?.

Sedangkan evaluasi terhadap pelatih yaitu kemapuan pelatih tidak dapat menjalankan tugas dan fungsinya sehingga program yang diharapkan tidak tercapai, maka perlu diadakan evaluasi “apakah pelatih tersebut masih dipertahankan atau di ganti?". Evaluasi terhadap pengelola yaitu jika ternyata pengelola tidak mampu menjalankan tugas dan fungsinya, maka perlu dievaluasi, "apakah pengelola tersebut masih dipertahankan atau di ganti?" Kriteria keberhasilan evaluasi proses pada indikator pengawasan adalah adanya kesesuaian proses evaluasi dengan ketentuan yang ada di sepak bola usia dini Jawa Barat. Berdasarkan pengecekan data antara hasil wawancara, studi dokumen dapat disimpulkan bahwa terdapat 
kesesuaian proses evaluasi di sepak bola usia dini dengan ketentuan pembinaan sepak bola usia dini di Jawa Barat.

\section{Evaluasi Produk}

Pencapaian Prestasi merupakan kata yang digunakan untuk menunjukan tingkat pencapaian seseorang dalam melakukan serangkaian kegiatan. Arti prestasi dalam kamus ilmiah adalah hasil yang telah dicapai. Pen capaian prestasi pada penelitian ini meliputi peningkatan perkembangan fisik/fisiologis, peningkatan perkembangan teknik, peningkatan perkembangan mental. Adapun hasil sebagai berikut: Hasil evaluasi produk dari 36 responden menyatakan 11 orang $(30,56 \%)$ menyatakkan baik sekali, 15 orang $(41,67 \%)$ menyatakan baik dan 4 oarang $(11,11 \%)$ menyatakan cukup serta yang menyatakan kurang 6 orang $(16,67 \%)$ adapun hasilnaya disajikan pada tabel berikut :

Tabel 4. Hasil Evaluasi Produk

\begin{tabular}{|c|c|c|c|}
\hline \multicolumn{3}{|c|}{ Frekuensi } & \multirow[b]{2}{*}{ Katagori } \\
\hline No & Absolut & Persentase & \\
\hline 1 & 11 & $30,56 \%$ & Baik sekali \\
\hline 2 & 15 & $41,67 \%$ & Baik \\
\hline 3 & 4 & $11,11 \%$ & Cukup \\
\hline \multirow[t]{2}{*}{4} & 6 & $16,67 \%$ & Kurang \\
\hline & 36 & $100 \%$ & \\
\hline
\end{tabular}

Tugas utama seorang pelatih adalah membantu atlet untuk meningkatkan prestasinya setinggi mungkin.Untuk mencapai tujuan tersebut pada penelitian ini diperhatikan pada peningkatan perkembangan fisik, teknik dan mental.

Peningkatan perkembangan fisik/fisiologis. Aspek fisik perlu dilatih untuk mempersiapkan fisik dalam menghadapi stress-stress fisik dan latihan dan pertandingan. Kecepatan, power,daya tahan otot, stamina dan agilitas serta kordinasi. Selama atlet menjalani proses latihan perkembangan atlet selalu terpantau melalui program evaluasi yang dilakukan oleh pelatih secara priodik. Hal ini terungkap melalui wawancara dengan pelatih fisik yang menyatakan bahwa evaluasi fisik dilakukan secara periodik setiap tiga bulan sekali. Berdasarkan hasil tersebut maka akan diketahui peningakatan perkembangan fisik.

Peningkatan perkembangan teknik. Latihan teknik adalah latihan untuk mempermahir keterampilan teknik-teknik gerakan spesialisasi masing-masing cabor, agar dengan setiap keterampilan gerakan dapat dilakukan sempurna mungkin. Berdasarkan hasil wawancara dengan pelatih teknik diperoleh data bahwa peningkatan perkembanagan teknik dapat dilihat selama proses latihan berlangsung dan juga dapat dilihat dari kejujuran, hasil try out maupun try in yang dilakukan sesuai periodesasinya. Masing-masing cabor akan berbeda sehingga setandar peningkatan keterampilan teknik disesuaikan denagan cabanag olahraga masing-masing.

Peningkatan perkembangan mental. Pada dasarkan peningkatan kemampuan atlet tidak terlepas dari aspek mental. Perkembangan mental atlet tidak kurang pentingnya dari 
perkembangan kemampuan fisik dan teknik. Latihan mental lebih menekankan pada perkembangan emosional implusif, misalnya motivasi berlatih, keseimbangan emosi terhadap stress, frustasi, kebimbangan, kemampuan meredam anxiety dan sebaginya. Latihan mental amat menonjol pentingnya bagi atlet, terutama mental bertanding. Kriteria keberhasilan evaluasi produk pada indikator pencapaian prestasi adalah adanya peningkatan perkembangan fisik/fisiologis, perkembangan teknik dan perkembangan mental. Berdasarkan pengecekan data antara hasil wawancara, studi, dokumen dapat disimpulkan atlet sepak bola usia dini Jawa Barat mengalami peningkatan perkembangan fisik/fisiologis, perkembangan teknik dan perkembangan mental hal ini tercermin dari hasil try-out, tyr-out in, kejuaraan bahkan tercermin selama proses latihan berlangsung.

Evaluai Prrogram CIPP (perlu ditambah analisisnya) Hasil evaluasi CIPP berdasarkan kuesioner yang disebar kepada 36 responden. Tanggapan 36 responden adalah 5,66\% (2orang) menyatakan baik sekali, 13,89\% (5 orang) menyatakan baik dan $80,56 \%$ (29 orang) menyatakan cukup. Adapun hasilnya disajikan pada tabel 5 sebagai berikut :

Tabel 5. Hasil Evaluasi CIPP

\begin{tabular}{lcll}
\hline & Frekuensi & & \\
\hline No & Absolut & Persentase & Katagori \\
\hline 1 & 2 & $5,56 \%$ & Baik sekali \\
\hline 2 & 5 & $13,89 \%$ & Baik \\
\hline 3 & 29 & $80,56 \%$ & Cukup \\
\hline 4 & 0 & $0 \%$ & Kurang \\
\hline
\end{tabular}

\section{KESIMPULAN}

Program pembinaan sepak bola usia dini merupakan program yang amat penting dalam upaya mernbina dan mengembangkan potensi-potensi dasar sepak bola agar mencapai prestasi yang tinggi di masa yang akan datang baik di tingkat daerah, nasional dan bahkan internasional. Berdasarkan evaluasi yang telah dilaksanakan dengan menggunakan model konteks, input, proses dan produk (C1PP) dapat menghasilkan beberapa kesimpulan, yaitu context, input, process, dan product.

\section{DAFTAR PUSTAKA}

Bompa, T. O., \& Haff, G. G. (2009). Periodization. Human Kinetics.

Danurwindo, Putera, G., \& Sidik, B. (2017). Kurikulum Pembinaan Sepakbola Indonesia. 1-11.

Fataha, I., Rahayu, T., \& KS, S. (2013). Evaluasi Program Pembinaan Sepakbola Klub Persigo Di Provinsi Gorontalo. Journal of Educational Research and Evaluation, 2(1).

Lazwardi, D. (2017). Implementasi Evaluasi Program Pendidikan Di Tingkat Sekolah Dasar Dan Menengah. Kependidikan Islam, 7(2), 67-79. 
Prawira, R. R. Z., \& Tribinuka, T. (2016). Pembinaan Pemain Muda Melalui. Jurnal Sains Dan Seni Its, 5(2), 13-17.

Sulistiyono. (2012). Transformasi Pengelolaan Klub Sepakbola Di Indonesia. Transformasi Pengelolaan Klub Sepakbola Di Indonesia, 2(2). https://doi.org/10.15294/miki.v2i2.2652

Tangkudung, J. (2012). Kepelatihan Olahraga dan Pembinaan Prestasi Olahraga. Cerdas Jaya.

Wargadinata, L. U., \& Ishak, M. (2018). Penalty kick skill through knee tuck jump exercise and barrier hops exercise. SHS Web of Conferences, 42, 00088. https://doi.org/10.1051/shsconf/20184200088

Winarno, M. E. (2004). Evaluasi Dalam Pendidikan Jasmani dan Olahraga.

Wirawan. (2011). Evaluasi Teori, Model, Standar, Aplikasi. RAJAWALI PERS.

Yunisal, P. (2017). Papat Yunisal, Sosok Tokoh Sepak Bola Wanita Asal Jawa Barat. https://doi.org/https://www.pssi.org/news 